\title{
Construction of Novel Yeast Strains from Candida tropicalis KBKTI 10.5.1 and Saccharomyces cerevisiae DBY1 to Improve the Performance of Ethanol Production Using Lignocellulosic Hydrolyzate
}

Jamaluddin Jamaluddin

IPB University Graduate School: Institut Pertanian Bogor Sekolah Pascasarjana

Eny Ida Riyanti ( $\nabla$ enyriyanti@gmail.com )

Indonesian Center for Agricultural Biotechnology and Genetic Resource Research and Development:

Balai Besar Litbang Bioteknologi dan Sumber Daya Genetik Pertanian

Nisa Rachmania Mubarik

IPB University: Institut Pertanian Bogor

Edy Listanto

Indonesian Center for Agricultural Biotechnology and Genetic Resource Research and Development: Balai Besar Litbang Bioteknologi dan Sumber Daya Genetik Pertanian

\section{Research Article}

Keywords: Biofuels, Fermentation, Genetic Engineering, Lignocellulosic, Yeast

Posted Date: March 7th, 2022

DOI: https://doi.org/10.21203/rs.3.rs-1356960/v1

License: (c) (i) This work is licensed under a Creative Commons Attribution 4.0 International License.

Read Full License 


\section{Abstract}

Increased consumption of xylose-glucose and yeast tolerance to lignocellulosic hydrolyzate are the keys to the success of second-generation bioethanol production. Candida tropicalis KBKTI 10.5.1 is a new isolated strain that has the ability to ferment xylose. In contrast to Saccharomyces cerevisiae DBY1 which only can produce ethanol from glucose fermentation. The research objective is the application of the genome sufling method to increase the performance of ethanol production using lignocellulosic hydrolyzate. Mutants were selected on xylose and glucose substrates separately and using RAPD analysis. The ethanol production using lignocellulosic hydrolyzate by parents and mutants was evaluated using a batch fermentation system. Concentrations of ethanol, residual sugars, and byproducts such as glycerol, lactate, and acetate were measured using HPLC machine uquiped with Hi-plex $\mathrm{H}$ for Carbohydrate column and a Refraction Index Detector (RID) detector. Ethanol produced by Fcs1 and Fcs 4 mutants on acid hydrolyzate increased by $26.58 \%$ and $24.17 \%$ from parent DBY 1 , by $14.94 \%$ and $21.84 \%$ from parent KBKTI 10.5.1. In contrast to the increase in ethanol production on alkaline hydrolyzate, Fcs1 and Fcs4 mutants only experienced an increase in ethanol production by $1.35 \%$ from the parent KBKTI 10.5.1. Ethanol productivity by Fcs1 and Fcs4 mutants on acid hydrolyzate reached $0.042 \mathrm{~g} / \mathrm{L} / \mathrm{h}$ and $0.044 \mathrm{~g} / \mathrm{L} / \mathrm{h}$. The recombination of the genomes of different yeast species resulted in novel yeast strains that improved resistance performance and ethanol production on lignocellulosic hydrolysates.

\section{Introduction}

Renewable and environmentally friendly energy sources such as biofuels from biomass is essential strategies for substituting the use of fossil energy [1]. The use of bioethanol has been proven to reduce carbon emissions compared to gasoline and diesel. The International Energy Agency (IEA) reports that the use of bioethanol is estimated to reduce carbon emissions by about 2.1 gigatons per year by 2050 if it is produced stably [2]. Bioethanol can be produced from abundant materials and can regenerate plants containing glucose, starch, and lignocellulose. Bioethanol production from lignocellulosic is more desirable than glucose and starch because socio-economically, sugar or starch leads to competition with food and feed needs $[3,4]$.

Many factors affect the productivity of ethanol production using lignocellulosic, including the lack of ability of microorganisms to ferment xylose-glucose and low viable in lignocellulosic hydrolyzate media $[5,4]$. The bioethanol production from xylose-glucose still uses a separate reactor since its inability or slower for co-fermenting both xylose and glucose [6]. In addition, hydrolysis proceses of lignocellulosic produce several inhibitor compounds such as furfural, HMF, vanillin, acetic acid, and formic acid which can decrease yeast viability to ethanol production $[7,8]$.

C. tropicalis KBKTI 10.5.1 1 can ferment xylose to produce ethanol, while S. cerevisiae DBY1 produce high ethanol concentration from glucose. Efforts to increase the ability to produce ethanol from xyloseglucose co-substrate continue to be carried out. Expression of xylose isomerase from Burkholderia 
cenocepacia to S. cerevisiae was performed [9], however, the resulting strain still consumes xylose very slowly compared to glucose and produces relatively low ethanol productivity. Efforts to increase the consumption of xylose-glucose have also been carried out with an adaptive evolution approach on media containing xylose [10]. Research with this approach has produced a yeast strain that ferment xyloseglucose quickly and almost simultaneously. However, reports on genetic improvement of yeasts to increase ethanol fermentation of xylose-glucose co-substrates and their tolerance to lignocellulosic hydrolysates very limited. The complexity of the regulation system of co-fermenting xylose-glucose to produce ethanol and the response of yeast to inhibitor compounds in lignocellulosic hydrolysates makes it challenging to engineer its metabolism by inserting and/or knocking out several genes responsible for the regulation system, and time consuming. Therefore, undirected mutation technology through the genome shuffling method has the potential to be developed to obtain superior yeast strains for lignocellulosic hydrolyzate fermentation.

Genome shuffling is a metabolic engineering method based on interprotoplast fusion. Protoplast fusion causes random recombination at the chromosomal level and can result in rapid multiplication of mutations so that the new strains formed have very diverse phenotypic properties [11]. Several studies have reported that genome shuffling can increase temperature and ethanol tolerance in S. cerevisiae 2013 [12] as well as increase productivity and ethanol tolerance in S. cerevisiae and Pichia stipites [13].

Therefore, potential new strains could be obtained from C. tropicalis KBKTI 10.5.1 and S. cerevisiae DBY1 to increase xylose-glucose fermentation and have high tolerance to lignocellulosic hydrolysates.

\section{Materials And Methods}

\section{Yeast Strains}

C. tropicalis KBKTI.10.5.1 and S. cerevisiae DBY1 were isolated from traditional Indonesian fermented foods that were carried out at the Molecular Biology Laboratory of the Indonesian Center for Agricultural Biotechnology and Genetic Resources Research (Indonesia). KBKTI.10.5.1 isolate was able to produce 0.8 $\mathrm{g} / \mathrm{L}$ ethanol from $20 \mathrm{~g} / \mathrm{L}$ xylose, while DBY1 could produce $21.98 \mathrm{~g} / \mathrm{L}$ ethanol from $50 \mathrm{~g} / \mathrm{L}$ glucose for 96 hours of incubation.

\section{Culture Preparation and Media Preparation}

Yeast isolates were cultured on YPD agar (1\% yeast extract, $2 \%$ peptone, 2\% D-glucose $2 \%$ agar) pH 5 for 24 hours. Seed culture for fermentation were prepared on liquid YPD media and incubated overnight at $30^{\circ} \mathrm{C}$ with $150 \mathrm{rpm}$ agitation.Seed culture, as much as $10 \%(\mathrm{v} / \mathrm{v})$ was used for fermentation.

Lignocellulosic hydrolyzate of elephant grass (Pennisetum purpureum Schum) was obtained from $10 \mathrm{~g}$ of lignocellulose dissolved in $50 \mathrm{~mL}$ of acid solution $(3 \% \mathrm{H} 2 \mathrm{SO}$ ) and alkaline solution $(3 \% \mathrm{NaOH})$ for 24 hours followed by high temperature and pressure treatment using autoclave. The $\mathrm{pH}$ of the lignocellulosic hydrolyzate was adjusted to 5 using $\mathrm{HCL}$ and $\mathrm{NaOH}$ solutions [14].

Genome Shuffling (GS) 
The construction of the novel strain was carried out by transferring DBY1 genomic DNA into KBKTI.10.5.1 cells using the genome shuffling method [15]. The GS step was carried out with slight modifications to the pretreatment solution using $0.1 \mathrm{M} \mathrm{CaCl}_{2}$. GS was carried out through electroporation technique using the MicroPulserTM 165-2100 electroporation system. A total of $100 \mu \mathrm{l}$ of GS results were spread into YPX media (1\% yeast extract, $2 \%$ peptone, $2 \%$ D-xylose, $2 \%$ agar) pH 5 and incubated for 3 days at $30^{\circ} \mathrm{C}$. The growing colonies were purified and mutants were selected.

\section{Mutant Selection}

Parent and mutants were inoculated into YPX and YPG agar (containing 1\% yeast extract, $2 \%$ peptone, 2\% $\mathrm{D}$-xylose/D-glucose, $2 \%$ agar $\mathrm{pH}$ 5) and incubated overnight at $30^{\circ} \mathrm{C}, 150 \mathrm{rpm}$. Cultures with $1 \mathrm{~mL}\left(\mathrm{OD}_{600}\right.$ $=0.5$ ) were inoculated into $9 \mathrm{~mL}$ of YPX and YPG media and incubated for 24 hours at $30^{\circ} \mathrm{C}, 150 \mathrm{rpm}$. The ability of wild types and mutants to produce ethanol from xylose and glucose was evaluated by measuring the concentration of ethanol and the remaining fermented liquid substrate using HPLC [14]. Mutant selection was also carried out through genome profile analysis using the Random Amplified Polymorphic DNA (RAPD) method with primers in Table 1.

Table 1

Random Amplified Polymorphic DNA (RAPD) Primers

\begin{tabular}{|ll|}
\hline Primers & Sequences $\left(\mathbf{5}^{\prime}-\mathbf{3}^{\prime}\right)$ \\
\hline OPB-12 & -CCT TGA CGC A- \\
OPX-03 & -TGG CGC AGT G- \\
OPX-06 & -ACG CCA GAG G- \\
\hline P-20 & -AGG AGA ACG G- \\
\hline
\end{tabular}

\section{Evaluation Of Cell Morphology And Genes Responsible For Ethanol Metabolism Of Selected Strains}

The selected strain cells were grown in YPD broth at $30^{\circ} \mathrm{C}$ for 48 hours. Cell cultures were prepared in a

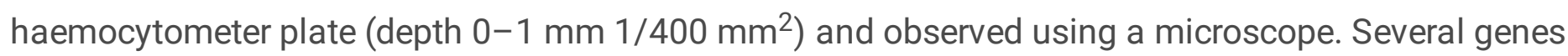
responsible for ethanol production and xylose utilization such as $x y / 1, a d h 1, x k s 1, p d c 1, p d c 5, p d c 6$ were confirmed qualitatively using PCR method. The primers used are presented in Table 2. 
Table 2

Primer pairs of genes that play a role in ethanol metabolism

\begin{tabular}{|c|c|c|}
\hline Primers & Sequences $\left(5^{\prime}-3^{\prime}\right)$ & Sources \\
\hline$x y / 1-\mathrm{F}$ & ATGTCTACTACTCCTACTATTCCTAC & \multirow[t]{2}{*}{ [16] } \\
\hline$x y / 1-\mathrm{R}$ & TTAAACAAAGATTGGAATGTTGTCCC & \\
\hline adh1-F & AGACGCGCATAACCGCTAGA & \multirow[t]{2}{*}{ [17] } \\
\hline $\operatorname{adh} 1-\mathrm{R}$ & TAAGATGTGCGCATCTTGGGA & \\
\hline$x k s 1-F$ & CCAGTGATATCGAGGATGAGATTAGTAC & \multirow[t]{2}{*}{ [18] } \\
\hline$x k s 1-\mathrm{R}$ & CCAGTGATATCTGTACTTGTCAGGGCAT & \\
\hline$p d c 1-\mathrm{F}$ & ACACCATCTTGGCTTTGGTC & \multirow[t]{2}{*}{ [19] } \\
\hline$p d c 1-\mathrm{R}$ & CGAAAGCTGGGAATTGAGTC & \\
\hline$p d c 5-\mathrm{F}$ & CACGTTGTTGGTGTTCCATC & \multirow[t]{2}{*}{ [19] } \\
\hline$p d c 5-\mathrm{R}$ & TCAGTGATCATGGCAGTGGT & \\
\hline pdc6-F & GGAGATTGACCCCAACAAGA & \multirow[t]{2}{*}{ [19] } \\
\hline$p d c 6-\mathrm{R}$ & ATACGGCTTTAACCCCCATC & \\
\hline
\end{tabular}

\section{Ethanol Fermentation, Hydrolyzed Sugar Analysis, Analysis of Fermentation Results}

Parent and mutants were grown in YPXG broth media (1\% yeast extract, $2 \%$ peptone, $2 \%$ D-xylose, $5 \%$ Dglucose) and elephant grass (Pennisetum purpureum Schum) lignocellulosic hydrolyzate medium ( $\mathrm{pH} 5)$. Fermentation was carried out for 72 hours on YPXG media and 24 hours on lignocellulosic hydrolyzate media at $30^{\circ} \mathrm{C}, 150 \mathrm{rpm}$. Observations were made every 24 hours on YPXG media and 4, 8, 24 hours on lignocellulosic hydrolyzate media. The content of xylose-glucose resulted from hydrolyzate lignocellulosic and its products such as ethanol, glycerol, lactate and acetate were analyzed using HPLC Agilent Technologies 1260 Infinity with a Hi-plex H for Carbohydrate column and a Refraction Index Detector (RID) detector [15].

\section{Kinetic Parameters And Data Analysis}

Cell biomass was obtained from the conversion of the $\mathrm{OD}_{600}$ value [20]. The ability of parental and mutant yeasts to consume xylose-glucose was calculated using Eq. 1

$$
\text { Percentageofxylose- glucoseconsumption }=\frac{S 0-S}{S 0} \times 100 \%
$$


where (SO) is the initial xylose-glucose level and (S) is the final total xylose-glucose. The results of each concentration of ethanol and cell biomass obtained were then used to calculate the kinetic parameters of ethanol production. The kinetic parameters of ethanol production include ethanol yield ( $\mathrm{Yp} / \mathrm{s})$, biomass yield ( $\mathrm{Yx} / \mathrm{s})$ and ethanol productivity (Qp) [21]

$\mathrm{Yp} / \mathrm{s}=\frac{P}{\Delta S}(2) \mathrm{Yx} / \mathrm{s}=\frac{X}{\Delta S}(3) \mathrm{Qp}=\frac{P}{\text { FermentationTime }}(4)$

The RAPD data obtained is based on the amplification band scoring with a classification of "1" if there is an amplified band and "0" if there is no amplified band. The data were then analyzed using the NTSYS-pc program (Numerical Taxonomy and Multivariate Analysis System, Version 2.02i). All ethanol production performance data were analyzed by simple mathematics using the excel program.

\section{Results}

\section{Selection of Potential Mutants for Ethanol Production from Xylose and Glucose}

The construction of new strains using genome suffling by transferring genomic DNA of DBY1 into KBKTI 10.5.1 cell produced mutants which increased in xylose consumption and ethanol production (Table 3). In the screening process using glucose and xylose substrates, variable sugar uptake and ethanol production were observed from the GS mutants. Mutant Fcs2 experienced a decrease in xylose consumption rate compared to the parent of KBKTI 10.5.1. While mutants Fcs1, Fcs3 and Fcs5 shows an increase in xylose consumption rate and Fcs4 mutant show an increase in ethanol production using xylose and glucose substrate (Table 3). This phenomenon illustrates that there is a change in the genetic component which changes in metabolism. This is supported by the different genomic profiles between parents and mutants based on RAPD analysis (Fig. 1).

The RAPD profile in Fig. 1.a illustrates that GS causes the transfer or substitution of nucleotide bases from DNA DBY1 to genomic DNA of KBKTI 10.5.1. The existence of insertion or substitution of nucleotide bases causes the RAPD primers used to attach or not during the PCR process so that polymorphisms are formed. The results of the RAPD analysis showed that there was random recombination between the genome of DBY1 and KBKTI 10.5.1. The RAPD profile of parental and mutant polymorphisms using the OPX-03 primer showed that the mutants similar to the KBKTI 10.5.1, but there was an additional DNA band at $2500 \mathrm{bp}$ as shown in the DBY1 profile. RAPD profiles with P-20 primer were found different between parent and mutans as band around 150 bp was do not detected in Fcs1, also band around 250 $\mathrm{pb}$ was not detected in in Fcs 5. The difference in RAPD amplicon profiles as shown in Fig. 1.a, indicates the presence of genetic diversity in the constructed mutants (Fig. 1.b). The resulting mutants were clustered in one cluster with the parent KBKTI 10.5.1. Fcs1 mutants were far apart to form separate subclusters at a genetic distance of 0.70. In addition, the Fcs4 and Fcs5 mutants grouped together to form a separate sub-cluster from the parent of KBKTI 10.5.1. The existence of genetic diversity produced can be 
an opportunity to produce superior strains. Fcs1 and Fcs4 mutants were then selected for further observation. Selection of Fcs1 and Fcs4 mutants based on the best ethanol production and xylose consumption compared to their parents.

Table 3

Test of ethanol production of parental and mutant yeasts using xylose and glucose

\begin{tabular}{|c|c|c|c|c|c|c|c|c|}
\hline \multirow{2}{*}{ Substrate $^{*}$} & \multirow{2}{*}{$\begin{array}{l}\text { Performa Produksi } \\
\text { Etanol }\end{array}$} & \multicolumn{7}{|c|}{ Yeast Isolate } \\
\hline & & $\mathrm{Sc}^{\star \star}$ & $\mathrm{Ct}^{\star \star}$ & Fcs1 & Fcs2 & Fcs3 & Fcs 4 & Fcs5 \\
\hline \multirow[t]{3}{*}{ Xylose } & $\begin{array}{l}\text { Total sugar } \\
\text { consumption }(\mathrm{g} / \mathrm{L})\end{array}$ & 0.04 & 1.94 & 2.22 & 1.86 & 2.52 & 1.91 & 2.14 \\
\hline & Ethanol products $(\mathrm{g} / \mathrm{L})$ & 0.00 & 0.32 & 0.32 & 0.39 & 0.24 & 0.39 & 0.24 \\
\hline & Substrate efficiency (\%) & 0.19 & 9.70 & 11.12 & 9.31 & 12.60 & 9.53 & 10.62 \\
\hline \multirow[t]{3}{*}{ Glucose } & $\begin{array}{l}\text { Total sugar } \\
\text { consumption }(\mathrm{g} / \mathrm{L})\end{array}$ & 19.89 & 19.53 & 19.65 & 19.56 & 19.60 & 19.56 & 19.62 \\
\hline & Ethanol products $(\mathrm{g} / \mathrm{L})$ & 7.34 & 6.94 & 6.94 & 7.02 & 7.02 & 7.02 & 7.02 \\
\hline & Substrate efficiency (\%) & 99.17 & 97.67 & 98.23 & 97.79 & 98.02 & 97.79 & 98.10 \\
\hline
\end{tabular}

$\mathrm{Ct}=$ C. tropicalis $\mathrm{KBKTI} 10.5 .1$

Genomic DNA of $C$. tropicalis KBKTI 10.5.1 has also been tried to be transferred into S. cerevisiae DBY1 cells, but the yeast strain obtained was still unable to produce ethanol from xylose (unpublished data). The failure of the construction of the new yeast strain for ethanol production from xylose using of strategy the KBKTI 10.5.1 genomic DNA transfer into DBY1 cells was thought to be because $S$. cerevisiae DBY1 does not have a xylose reductase gene sequence, a gene that plays a role in catalyzing xylose to enter ethanol metabolism [22, 23]. Thus, the DNA sequence of the KBKTI 10.5.1 xylose reductase gene was not successfully inserted into DBY1 DNA because there was no homology between the two sequences.

\section{Evaluation of Cell Morphology and Genes Responsible for Ethanol Metabolism of Selected Mutant}

The novel yeast strains that were constructed had morphological characters of cells which were thought to be inherited from the two parents. The two mutant cells were spherical in shape more closely resembled parental KBKTI 10.5.1 compared to the slightly oval shape of DBY1 cells. However, the mutant cells did not form pseudohyphae like the parents of KBKTI 10.5 .1 which had been incubated at $30^{\circ} \mathrm{C}$ for 48 hours simultaneously with the two parents (Fig. 2).

In addition to cell morphology observations, several genes that play a role in ethanol metabolism were also evaluated qualitatively. Figure 3.a, shows that KBKTI 10.5.1 and both mutants have the same 
amplicon xylose reductase profile, which was around $1000 \mathrm{bp}$. However, the results of the sequence alignment analysis showed that there were four nucleotide base differences (Fig. 3.b). This indicated that the transfer of DBY1 DNA into KBKTI 10.5.1 cells caused a change in the nucleotide base arrangement in the KBKTI 10.5.1 genome. The results of the analysis of sequence homology in the BLAST-n program showed that the xylose reductase KBKTI 10.5.1 was identical to the xylose reductase Candida tropicalis isolate GRA1 (99.59\%) while the Fcs1 mutant changed to $99.28 \%$ against the xylose reductase isolate GRA1 gene. Changes in the arrangement of four nucleotide bases can change the amino acid composition of the mutant, this is indicated by the results of BLAST-p xylose reductase KBKTI 10.5.1 which has a homology percentage of $96.96 \%$ and Fcs 1 xylose reductase reaches $96.27 \%$ against DXylose reductase Candida tropicalis (QED90344 .1).

The gene encoding pyruvate decarboxylase were also different. The results of the study in Fig. 4.b show that there are several bands generated from the $p d c 5$ and $p d c 6$ PCR primers. This shows that the primer used is not yet specific. However, it can be seen that with $p d c 5$ and $p d c 6$ primers, Fcs 1 and Fcs 4 mutants are different from their parents. Differences in the amlicone profile of the gene encoding pyruvate decarboxylase may support differences in the production of by-products (lactate, acetate, and glycerol), as shown in Fig. 4

\section{Performance of Wild Type and Mutant Yeast for Ethanol Production on YPXG Media and Elephant Grass ( Pennisetum purpureum Schum) Lignocellulosic Hydrolyzate}

Yeast strains capable of fermenting xylose-glucose to produce high ethanol concentrations are one of the keys to the success of ethanol production using lignocellulosic [24]. Our results showed that the KBKTI 10.5.1 strain as well as the two constructed mutants had the ability to produce approximately $2 \%$ ethanol from xylose-glucose fermentation for 72 hours (Fig. 4). However, the ability to use xylose-glucose between parents and mutants was different. The DBY1, KBKTI 10.5.1 and the Fcs4 mutant were not able to use xylose-glucose simultaneously, in contrast to the Fcs1 mutant which was able to use xylose when glucose was still available in the medium. In addition, the consumption of xylose by the Fcs 1 mutant was slightly higher than that of the two parents, but there was no increase in ethanol production. This phenomenon is thought to occur because the consumed xylose was converted to lactate, this can be seen from the increase in lactate production as the xylose concentration in the media decreases (Fig. 4). However, Fcs1 and Fcs4 mutants are potential to be used as second generation bioethanol production agents with further research on process engineering to minimize the formation of side products such as lactate, acetate and glycerol.

The results of the study as shown in Fig. 4 can be seen that the use of xylose at a mixed concentration of 20-50 g/L xylose-glucose has not been able to significantly increase ethanol production. The research report showed that Pichia kudriavzevii and $C$. tropicalis experienced an increase of ethanol production at a 1:1 xylose-gluose mixture [25]. Therefore, it is necessary to optimize the concentration of the xyloseglucose mixture to increase ethanol production. In addition to substrate concentration, the ability to produce ethanol using lignocellulosic is also influenced by the presence of inhibitors produced in the 
hydrolysis process $[26,27]$. Therefore, this study also reports the performance of ethanol by parental and mutant strains in lignocellulosic hydrolyzate media presented as in Figs. 5, 6.

Elephant grass (Pennisetum purpureum Schum) is one of the potential raw materials for bioethanol production [28]. Elephant grass biomass contains $60.20 \%$ cellulose, $23.80 \%$ hemicellulose [29] which can be hydrolyzed into xylose and glucose. However, the concentration of sugar (xylose-glucose) obtained from the hydrolysis of acids and bases in this study was very low, reaching only $4.18 \mathrm{~g} / \mathrm{L}$ and $1.77 \mathrm{~g} / \mathrm{L}$ (Fig. 5, Fig. 6). This can indicate that the hydrolysis of elephant grass biomass using acids and bases combined with pressure has not been maximized to increase the concentration of glucose and xylose. Sugar concentration below $10 \mathrm{~g} / \mathrm{L}$ in bioethanol fermentation is not recommended because it can produce very little ethanol (Faizal et al., 2020). However, the results of our study need to be reported because through the production of bioethanol using lignocellulosic hydrolysates, the information on the ability to consume xylose-glucose and the growth ability of yeast strains that us obtained on the hydrolyzate can be known.

The performance of xylose-glucose consumption between parents and mutants on both acid and alkaline hydrolyzate media showed that the two mutants were more similar to the parents of KBKTI 10.5.1. (Fig. 5, Fig. 6). The ability to consume glucose by DBY1 on acid hydrolyzate media seemed to slow down, where at 4 hours glucose was still available compared to the other three strains that had been used up. This is one of the effects of the concentration of ethanol produced being lower than the parent KBKTI 10.5.1 and the two mutants (Fig. 5). The results in Fig. 5 also show that at the concentration of the xylose-glucose mixture of about 3:1, the parent of KBKTI 10.5.1 and both mutants were able to use xylose-glucose simultaneously. This is indicated by the significant use of xylose at 4 hours (Fig. 5). In addition, the ability to grow mutants on acid hydrolyzate media was better when compared to the two parents, this was indicated by the high $\mathrm{OD}_{600}$ value and a slight increase in ethanol production (Fig. 5). The use of xyloseglucose by the parents of KBKTI 10.5.1 and the two mutants in alkaline hydrolyzate media showed that they were used simultaneously (Fig. 6), but were not able to increase ethanol production. This was thought to be caused by the very low concentration of total substrate sugar, so that the sugar consumed was widely used for cell growth.

\section{Productivity of Parent and Mutant Yeast on Lignocellulosic Hydrolyzate Media}

The ability of bioethanol production by the parents and the resulting new strains are different. This difference can also be seen from the kinetic parameters as shown in Table 4. The ethanol productivity of the parents on YPXG media with a composition of $20-50 \mathrm{~g} / \mathrm{L}$ xylose was better than that of the mutant, but on acid hydrolyzate the ethanol productivity of the new strain was better. This can indicate that genomic recombination between the two parents resulted in improved productivity of resistance to lignocellulosic hydrolysates. The conversion of xylose-glucose to ethanol by strains Fcs1 and Fcs4 on acid hydrolyzate media was also quite efficient. This can be seen from the product yield which reached $0.37 \mathrm{~g} / \mathrm{g}$. The xylose-glucose conversion efficiency of strains Fcs1 and Fcs4 was almost equivalent to the 
conversion of hexose with the addition of a lignocellulosic inhibitor by Saccharomyces cerevisieae isolate ISO12, which was $0.38 \mathrm{~g} / \mathrm{g}$, in which the IS012 strain was claimed to be one of the superior candidates for the production of second generation bioethanol $[30,14]$.

Table 4

Parameters of parental and mutant yeast kinetics on different media

\begin{tabular}{|c|c|c|c|c|c|c|c|}
\hline Isolate & Medium* & $\begin{array}{l}\text { Fermentation } \\
\text { Time (h) }\end{array}$ & $\begin{array}{l}\text { Percentage of Xylose- } \\
\text { Glucose Consumption } \\
\text { (\%) }\end{array}$ & $\begin{array}{l}\text { Ethanol } \\
(\mathrm{g} / \mathrm{L})\end{array}$ & $\begin{array}{l}Y p / s \\
(g / g)\end{array}$ & $\begin{array}{l}Y x / s \\
(g / g)\end{array}$ & $\begin{array}{l}\mathrm{Qp} \\
(\mathrm{g} / \mathrm{L} / \mathrm{h})\end{array}$ \\
\hline \multirow[t]{3}{*}{ Sc } & YPXG & 72 & 74.90 & 18.66 & 0.36 & 0.04 & 0.259 \\
\hline & $\mathrm{HA}$ & 24 & 30.37 & 0.79 & 0.67 & 0.35 & 0.033 \\
\hline & $\mathrm{HB}$ & 24 & 77.05 & 0.78 & 0.61 & 0.18 & 0.033 \\
\hline \multirow[t]{3}{*}{ Ct } & YPXG & 72 & 76.79 & 18.08 & 0.33 & 0.03 & 0.251 \\
\hline & $\mathrm{HA}$ & 24 & 69.60 & 0.87 & 0.31 & 0.23 & 0.036 \\
\hline & $\mathrm{HB}$ & 24 & 100 & 0.74 & 0.45 & 0.25 & 0.031 \\
\hline \multirow[t]{3}{*}{ Fcs1 } & YPXG & 72 & 78.30 & 17.91 & 0.33 & 0.03 & 0.249 \\
\hline & $\mathrm{HA}$ & 24 & 69.60 & 1.00 & 0.37 & 0.29 & 0.042 \\
\hline & $\mathrm{HB}$ & 24 & 100 & 0.75 & 0.47 & 0.20 & 0.031 \\
\hline \multirow[t]{3}{*}{ Fcs 4} & YPXG & 72 & 77.63 & 17.94 & 0.33 & 0.03 & 0.249 \\
\hline & $\mathrm{HA}$ & 24 & 71.76 & 1.06 & 0.37 & 0.29 & 0.044 \\
\hline & $\mathrm{HB}$ & 24 & 100 & 0.75 & 0.46 & 0.22 & 0.031 \\
\hline
\end{tabular}

\section{Discussion}

The constructed novel strain has a different physiology from the two wild types. Among the different physiological properties are the ability to produce ethanol from xylose, glucose and cause differences in cell morphology such as the formation of pseudohyphae. Pseudohyphae are formed from shoot cells, such as blastospores, which multiply, but the daughter cells do not separate from the parent cell and continue to elongate to resemble hyphae, so that there is a septum between the blastospore and the growing part of the cell, and in this section there is a narrowed part [31]. The formation of pseudohyphae is closely related to the physiological properties of cells which are influenced by several factors such as nitrogen deficiency [32, 33], CO2 exposure [34], high phosphate and growth period [31], growing temperature conditions [35]. The results of cell morphology observations as shown in Fig. 2 can illustrate that the physiological roles of parent and mutant in responding to environmental conditions (nutrients in 
YPD media, temperature and incubation time) were different. The difference in phenotype of an organism is part of the influence of its genetic expression [36]. Therefore, the transfer of DBY1 DNA to KBKTI 10.5.1 cells was suggested to cause the insertion of genetic material into the KBKTI 10.5.1 genome, thereby causing changes in some genetic expressions.

The novel strain that was constructed experienced an increase in the ability to consume xylose and produce ethanol. Yeast strains capable of fermenting xylose cannot use xylose until the glucose concentration is completely depleted. This can be explained by several factors, including because glucose can suppress the expression of genes responsible for xylose metabolism through the transcription factor Mig1. Cells that are in high glucose concentrations cause Mig1 to move from the cytoplasm to the nucleus and bind to gene promoters that can cause repression of xylose catabolism genes. After the glucose concentration in the medium decreases, the transcription factor Mig1 is transported back to the cytoplasm so that the repression is released [37]. This is one of the factors that slows down ethanol production in the presence of xylose in the media. High glucose concentration in the xylose-glucose mixture is one of strategy to increase ethanol production. This can be seen from the ability of the parent and mutant for 24 hours to produce ethanol around 6.94-7.34 g/L from the fermentation of $20 \mathrm{~g} / \mathrm{L}$ glucose (Table 3), compared to a mixture of $20-50 \mathrm{~g} / \mathrm{L}$ xylose-glucose already can produce ethanol about 17-18 g/L (Fig. 4). Moreover, the study results need to be reported because the constructed mutants have an increased ability to consume xylose (Table 3 ) and can even be used in conjunction with glucose (Fig. 4, Fig. 5, Fig. 6).

Yeast cells are the main engine in fermentation, having the potential to be exposed to various types of fermentation stresses such as osmotic stress, temperature stress, ethanol stress and the presence of toxic compounds during the fermentation process $[38,39]$. The resistance of yeast cells in responding to fermentation stress is an important factor that must be possessed by a fermentation agent. There is a direct relationship between fermentation efficiency and yeast resistance to stress which refers to the ability of yeast lines to adapt efficiently to unfavorable growing conditions [40]. Lignocellulosic hydrolyzate can produce several mixtures of inhibitor compounds that can inhibit ethanol production, cell growth, and enzyme biochemical activity [41]. Therefore, $\mathrm{OD}_{600} \mathrm{~nm}$ in Fig. 5, 6, showed that the newly obtained lines experienced faster growth in the lignocellulosic hydrolyzate than the parent. This can represent the ability of tolerance and good productivity to the presence of toxic compounds lignocellulosic hydrolyzate.

Yeast cells that grow undergo a mechanism of nutrient transport and assimilation accompanied by the integration of nutrients into cellular components, so that there is an increase in biomass and cell division. The main purpose of growing yeast cells is to multiply cells rather than produce ethanol [42]. However, during fermentation, ethanol production and yeast growth are closely related processes. Therefore, the ability to transport xylose-glucose hydrolyzate lignocellulosic is one of the factors that affect the productivity of ethanol production. The genomic recombination of KBKTI 10.5.1 and DBY1 succeeded in improving the genes responsible for xylose-glucose transport to cells, this was indicated by an increase in xylose-glucose consumption in Fcs1 and Fcs4 mutants by 3.64\% - 4.54\% from DBY1 and 1.09\% -1.97\% 
from KBKTI 10.5.1 on YPXG media. An increase in xylose-glucose consumption also occurred in both acidic and basic hydrolyzate media (Table 4).

\section{Conclusion}

Novel strains of Fcs 1 and Fcs4 were obtained with different $x y / 1$ and $p d c 5$ genes from the Candida tropicalis KBKTI 10.5.1 and Saccharomyces cerevisiae DBY1. The performance of xylose-glucose consumption and ethanol productivity of Fcs1 and Fcs4 mutant on lignocellulosic hydrolyzate increased compared to their parents. The ethanol productivity of the Fcs 1 mutant increased by $16.67 \%-27.27 \%$, while the Fcs 4 mutant reached $22.22 \%-33.33 \%$ of the parental KBKTI 10.5 .1 and DBY1 on acid hydrolyzate.

\section{Declarations}

\section{Acknowledgement}

The authors would like to thank the Indonesian Centre for Biotechnology and Genetic resources Research and Development, Indonesian Agency for Agricultural Research and Development.

\section{Author contributions}

J., E.I.R., N.R.M., E.L. jointly formulated the research concepts, methods, data analysis and writing of this manuscript.

\section{Funding}

This research was funded by Indonesian Centre for Biotechnology and Genetic resources Research and Development, Indonesian Agency for Agricultural Research and development, Indonesian Ministry of Agriculture, DIPA 2021, register number DIPA:4584.SDA.503.052.A.

\section{Declaration of Competing Interest}

The autors state that there has no conflict of interest to be reported.

\section{Ethics approval}

This article does not contain any studies with human participants or animals performed by any of the authors.

\section{References}

1. Morais, R.F., Morais, C.S.B., de Morais L.F, Almeida, J.C.C., 2018. Energy balance of elephant grass biomass for power generation by direct biomass combustion. J. Biotechnol. 17 (13), 405-410. 
2. Jin, E., Sutherland, J.W., 2016. A proposed integrated sustainability model for a bioenergy system. Procedia CIRP. 48, 358-363.

3. Meneses, L.R., Raud, M., Orupold, K., Kikas, T., 2017. Second-generation bioethanol production: A review of strategies for waste valorization. Agronomy Research. 15 (3), 830-847.

4. Robak, K., Balcerek, M., 2018. Review of second generation bioethanol production from residual biomass. Food Technology and Biotechnology. 56 (2), 174-187.

5. Bušić, A., Marđetko, N., Kundas, S., Morzak, G., Belskaya, H., Šantek, M.I., Komes, D., Novak, S., Šantek, B., 2018. Bioethanol production from renewable raw materials and its separation and purification: A review. Food Technol. Biotechnol. 56 (3), 289-311.

6. Cardona, C.A., Sa'nchez, O.J., 2007. Fuel ethanol production: Process design trends and integration opportunities. Bioresource Technology. 98, 2415-2457.

7. Riyanti E.I., Listanto, E., 2017. Inhibiton of the growth of tolerant yeast Saccharomyces cerevisiae strain 1136 by a mixture of synthetic inhibitors. Indonesian Journal of Agricultural Science. 18 (1), 1724.

8. Sjulander, N., Kikas, T., 2020. Origin, impact and control of lignocellulosic inhibitors in bioethanol production-A Review. 13, 4751, doi:10.3390/en13184751

9. Vilela, L.D.F., Mello, V.M.D., Reis, V.C.B., Bon, E.P.D.S., Torres, F.A.G., Neves, B.C., Eleutherio, E.C.A., 2013. Functional expression of Burkholderia cenoceparia xylose isomerase in yeast increase ethanol production from a glucose-xylose blend. Bioresource Technology. 128, 792-796.

10. Vilela, L.D.F., Araujo, V.P.G.D., Paredes, R.D.S., Bon, E.P.D.S., Torres, F.A.G., Neves, B.C., Eleutherio, E.C.A., 2015. Enhanced xylose fermentation and ethanol production by engineered Saccharomyces cerevisiae AMB Express. 5 (1), 16. doi:10.1186/s13568-015-0102-y

11. Biot-Pelletier, D., Martin, V.J.J., 2014. Evolutionary engineering by genome shuffling. Appl Microbiol Biotechnol. 98, 3877-3887.

12. Orosco, F.L., Estrada, S.M., Simbahan, J.F., Alcantara, V.A., Pajares, I.G., 2017. Genome shuffling for improved thermotolerance, ethanol tolerance and ethanol production of Saccharomyces cerevisiae Philippine Science Letters. 10 (1), 22-28.

13. Jetti, K.D., GNS, R.R., Garlapati, D., Nammi, S.K., 2018. Improved ethanol productivity and ethanol tolerance through genome shuffling of Saccharomyces cerevisiae and Pichia stipites. International Microbiology. https://doi.org/10.1007/s10123-018-00044-2.

14. Riyanti El, Yuniawati R, Sanjaya RA, Samudra IM, Listanto E, Lestari EG, Mastur. 2020. Potential use of Saccharomyces cerevisiae TKPK 10.5.1 isolated from several sources for ethanol using various sugar sources. AIP Conference Proceeding 2260, 060004-1-060004-9; https://doi.org/10.1063/5.0015968.

15. Zhang, W., Geng, A., 2012. Improved ethanol production by a xylose-fermenting recombinant yeast strain contructed through a modified genome shuffling method. Biotechnology for Biofuels. 5 (1), 46. doi:org/10.1186/1754-6834-5-46 
16. Kim, S., Lee, J., Sung, B.H., 2019. Isolation and characterization of the stress-tolerant Candida tropicalis $\mathrm{YHJ} 1$ and evaluation of its xylose reductase for xylitol production from acid pre-treatment wastewater. Frontiers in Bioengineering and Biotechnology. 7, 138.doi: 10.3389/fbioe.2019.00138

17. Smidt, O., Preez, J.C., Albertyn, J., 2012. Molecular and physiological aspects of alcohol dehydrogenases in the ethanol metabolism of Saccharomyces cerevisiae. FEMS Yeast Res. 12, 3347

18. Richard, P., Toivari, M.H., Penttila, M., 2000. The role of xylulokinase in Saccharomyces cerevisiae xylulose catabolism. FEMS Microbiology Letters. 190, 39-43.

19. Kahar, P., Riyanti, E.I., Otsuka, H., Matsumoto, H., Kihira, C., Ogino, C., Kondo, A., 2017. Challenges of non-flocculating Saccharomyces cerevisiae haploid strain against inhibitory chemical complex for ethanol production. Bioresource Technology. 245, 1436-1446.

20. Myers, J.A., Curtis, B.S., Curtis, W.R., 2013. Improving accuracy of cell and chromophore concentration measurements using optical density. BMC Biophysics. 6 (1), 4. http://www.biomedcentral.com/2046-1682/6/4

21. Moremi, M.E., Rensburg, E.L.J.V., Grange, D.C.L., 2020. The improvement of bioethanol production by pentose-fermenting yeasts isolated from herbal preparations, the gut of dung beetles, and marula wine. International Journal of Microbiology. 1-13. https://doi.org/10.1155/2020/5670936

22. Mouro, A., Santos, A.A.D., Agnolo, D.D., Gubert, G.F., Bon, E.P.S., Rosa, C.A., Fonseca, C., Stambuk, B.U., 2020. Combining xylose reductase from Spathaspora arborariae with xylitol dehydrogenase from Spathaspora passalidarum to promote xylose consumption and fermentation into xylitol by Saccharomyces cerevisiae. Fermentation. 6(72), doi:10.3390/fermentation6030072

23. Olofsson, K., Runquist, D., Hahn-Hägerdal, B., Lidén, G., 2011. A mutated xylose reductase increases bioethanol production more than a glucose/xylose facilitator in simultaneous fermentation and cofermentation of wheat straw. AMB Express. 1(4), http://www.amb-express.com/content/1/1/4

24. Zabed, H., Sahu, J.N., Boyce, A.N., Faruq, G., Fuel ethanol production from lignocellulosic biomass: An overview on feedstocks and technological approaches. Renewable and Sustainable Energy Reviews. 66, 751-774

25. Nweze, J.E., Ndubuisi, I., Murata, Y., Omae, H., Ogbonna, J.C., 2019. Isolation and evaluation of xylose-fermenting thermotolerant yeasts for bioethanol production. Biofuels. 1-10. https://doi.org/10.1080/17597269.2018.1564480

26. Faizal, A., Sembada, A.A., Priharto, N., 2020. Production of bioethanol from four species of duckweeds (Landoltia punctata, Lemna aequinoctialis, Spirodela polyrrhiza, and Wolffia arrhiza) through optimization of saccharification process and fermentation with Saccharomyces cerevisiae. Saudi Journal of Biological Sciences. 28, 294-301.

27. Chaudhary, A., Hussain, Z., Aihetasham, A., El-Sharnouby, M., Rehman, R.A., Khan, M.A.U., Zahra, S., Saleem, A., Azhar, S., Alhazmi, A., El Askary, A., Sayed, S., El Enshasy, H. A., Hanapi, S.Z., Qamer, S., 2021. Pomegranate peels waste hydrolyzate optimization by response surface methodology for bioethanol production. Saudi Journal of Biological Sciences. 28(9), 4867-4875 
28. Vidal, A.K.F., Barbé, T.D., Daher, R.F., Filho, J.E.A., Lima, R.S.N., Freitas, R.S., Rossi, D.A., Oliveira, E.S., Menezes, B. R.S., Entringer, G.C., Peixoto, W.F.S., Cassaro, S., 2017. Production potential and chemical composition of elephant grass (Pennisetum purpureum) at different ages for energy purposes. African Journal of Biotechnology. 16(25), 1428-1433

29. Minmunin, J., Limpitipanich, P., Promwungkwa, A., 2015. Delignification of elephant grass for production of cellulosic intermediate. Energy Procedia. 79, 220 - 22534.

30. Wallace-Salinas, V., Gorwa-Grauslund, M.F., 2013, Adaptive evolution of an industrial strain of Saccharomyces cerevisiae for combined tolerance to inhibitors and temperature. Biotechnology for Biofuels. 6:151. http://www.biotechnologyforbiofuels.com/content/6/1/151

31. Veses, V., Gow, N.A.R., 2009. Pseudohypha budding patterns of Candida albicans. Medical Mycology. 47, 268-275. doi: 10.1080/13693780802245474

32. Lackey, E., Vipulanandan, G., Childers, D.S., Kadosh, D., 2013. Comparative evolution of morphological regulatory functions in Candida Eukaryotic Cell. 12(10), 1356-1368

33. 34 González, B., Vázquez1, J., Cullen, P.J., Mas, A., Beltran1, G., Torija, M., 2018. Aromatic amino acidderived compounds induce morphological changes and modulate the cell growth of wine yeast species. Frontiers In Microbiology. 9, doi: 10.3389/fmicb.2018.00670

34. Sasani, E, Khodavaisy, S., Agha, K.A.S., Darabian, S., Rezaie, S., 2016. Pseudohyphae formation in Candida glabrata due to CO2 exposure. Curr Med Mycol. 2(4), 49-52.

35. Nadeem, S.G., Shafiq, A., Hakim, A.T., Anjum, Y., Kazm, S.U., 2013. Effect of growth media, pH and temperature on yeast to hyphal transition in Candida albicans. Journal of Medical Microbiology. 3 , 185-192.

36. Young, A.I., Benonisdottir, S., Przeworski, M., Kong, A., 2019. Deconstructing the sources of genotypephenotype associations in humans. Science. 365(6460), 1396-1400.

37. Rolland, F., Winderickx, J., Thevelein, J.M., 2002. Glucose-sensing and - signaling mechanisms in khamir. FEMS Yeast Research. 2(2), 183-201.

38. Burphan, T., Tatip, S., Limcharoensuk, T., Kangboonruang, K., Boonchird, C., Auesukaree, C., 2018. Enhancement of ethanol production in very high gravity fermentation by reducing fermentationinduced oxidative stress in Saccharomyces cerevisiae. Sci Rep. 8, 13609.

39. Mukherjee, V., Steensels, J., Lievens, B., de Voorde, I.V., Verplaetse, A., Aerts, G., Willems, K.A., Thevelein, J.M., Verstrepen, K.J., Ruyters, S., 2014. Phenotypic evaluation of natural and industrial Saccharomyces yeasts for different traits desirable in industrial bioethanol production. Appl Microbiol Biotechnol. 98 (22), 9483-9498.

40. Saini, P., Beniwal, A., Vij, S., 2017. Comparative analysis of oxidative stress during aging of Kluyveromyces marxianus in synthetic and whey media. Appl Biochem Biotechnol. 183 (1), 348-361.

41. Palmqvist, E., Hahn-Hagerdal, B., 2000. Fermentation of lignocellulosic hydrolysates. Il: inhibitors and mechanisms of inhibition Bioresource Technology. 74, 25-33.

42. Walker, G.M., Stewart, G.G., 2016. Saccharomyces cerevisiae in the production of fermented beverages. 2, 30. doi:10.3390/beverages2040030 


\section{Figures}

a

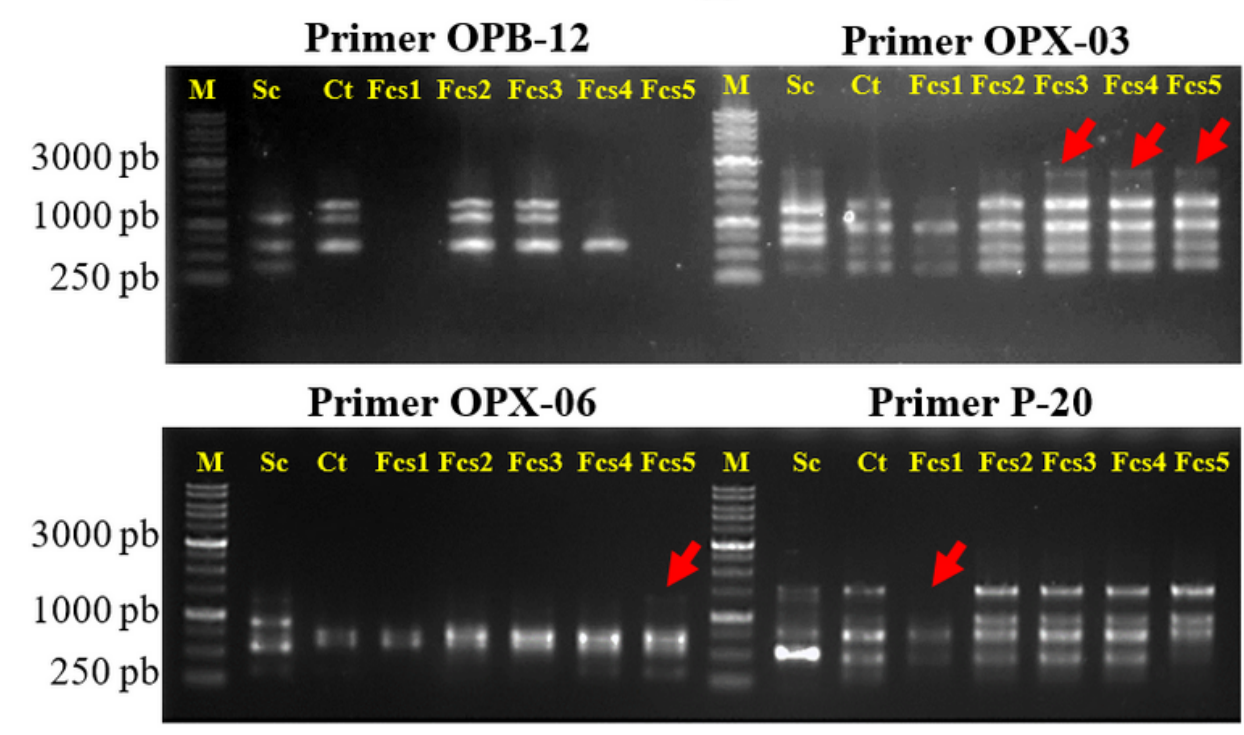

b

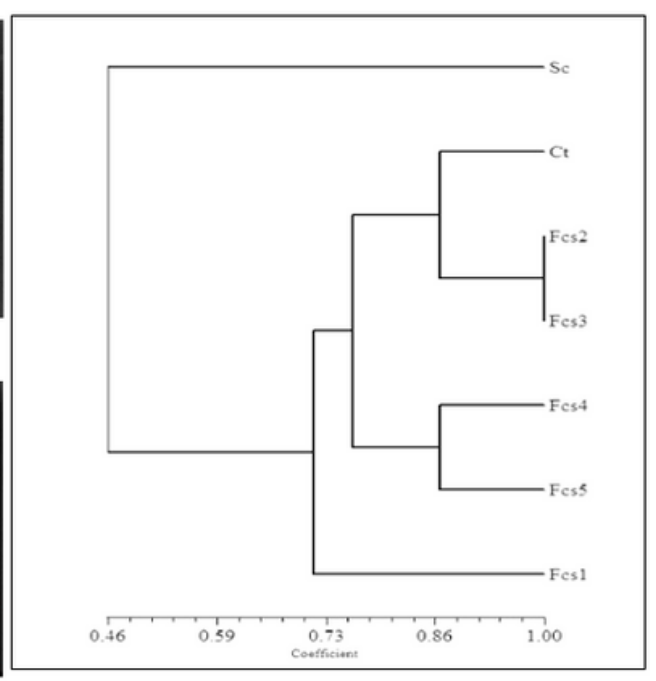

\section{Figure 1}

a) Electrophorogram profile of parental and mutant yeast RAPD genomes, on $1 \%$ agarose. $M=1 \mathrm{~kb}$ Ladder DNA, $\mathrm{Sc}=$ S. cerevisiae $D B Y 1, \mathrm{Ct}=C$. tropicalis $\mathrm{KBKTI} 10.5 .1 ., \mathrm{b})$ Cluster analysis of mutant strains constructed with SAHN-UPGMA.
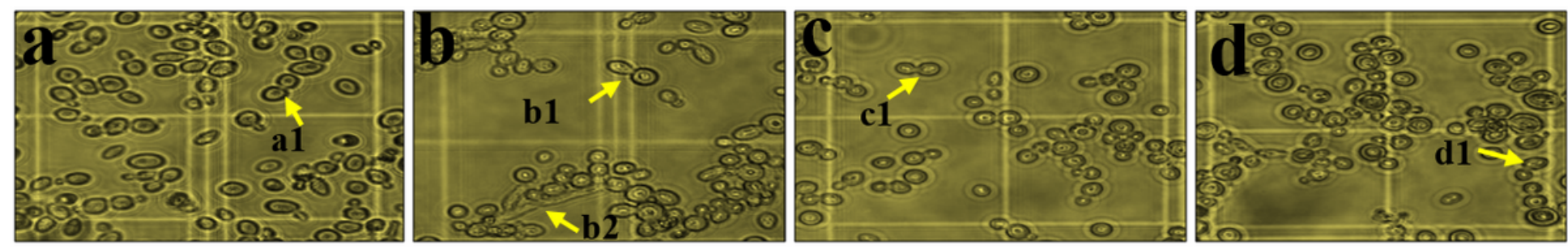

Figure 2

Morphology of parental and mutant cells grown on media YPD, $a=$ DBY1, $b=$ KBKTI 10.5.1, $c=$ Fcs1, $d=$ Fcs4, a1,b1,c1,d1 = budding, b2 = pseudohyphae. Observation of cell morphology using a microscope at 200X magnification. 


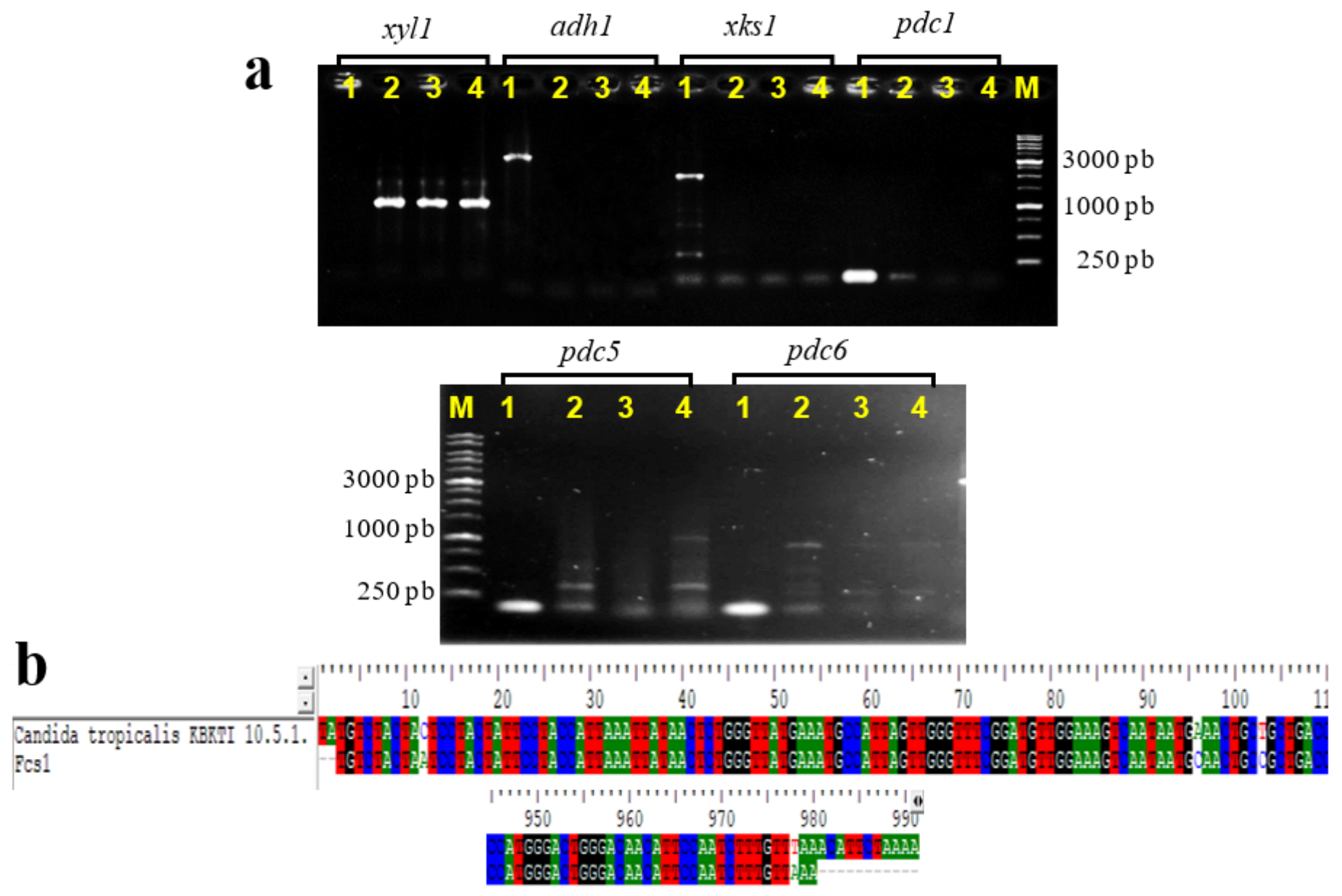

Figure 3

a) Electrophorogram of several genes that play a role in ethanol metabolism, b) Sequence alignment analysis results using the Bioedit program 
S. cerevisiae DBY1

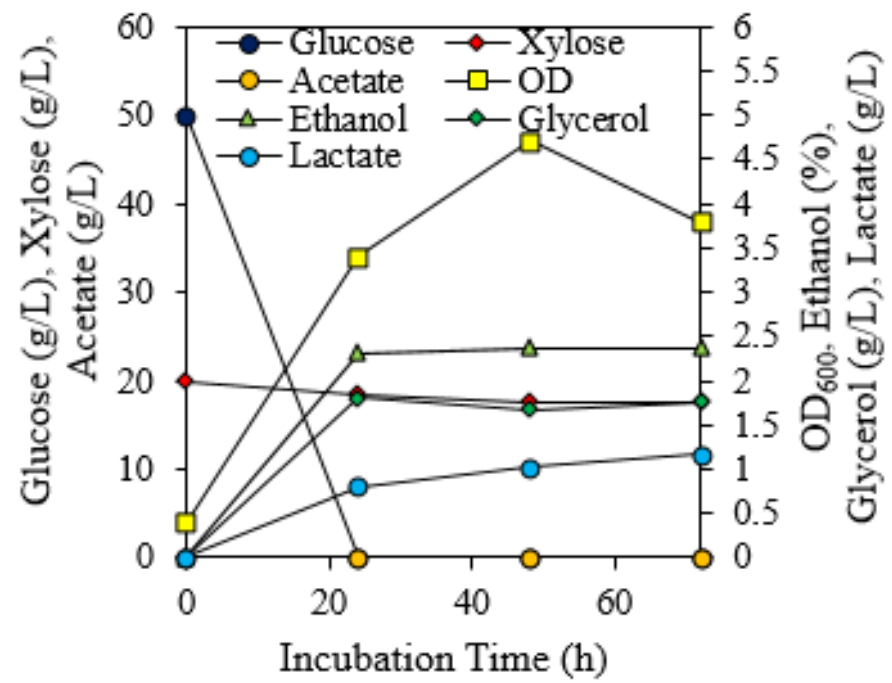

Fcs 1

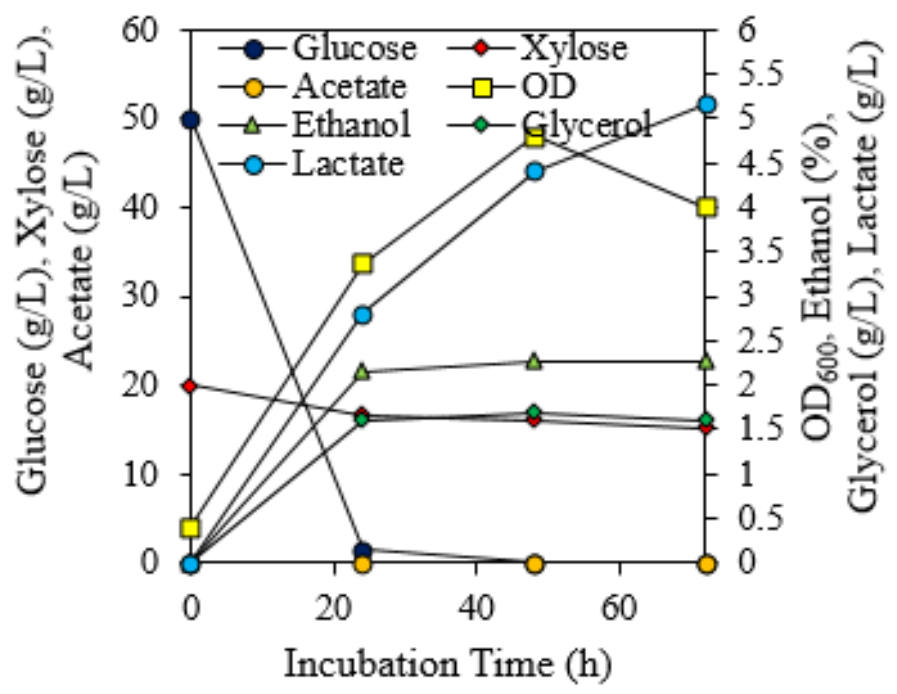

C. tropicalis KBKTI 10.5.1

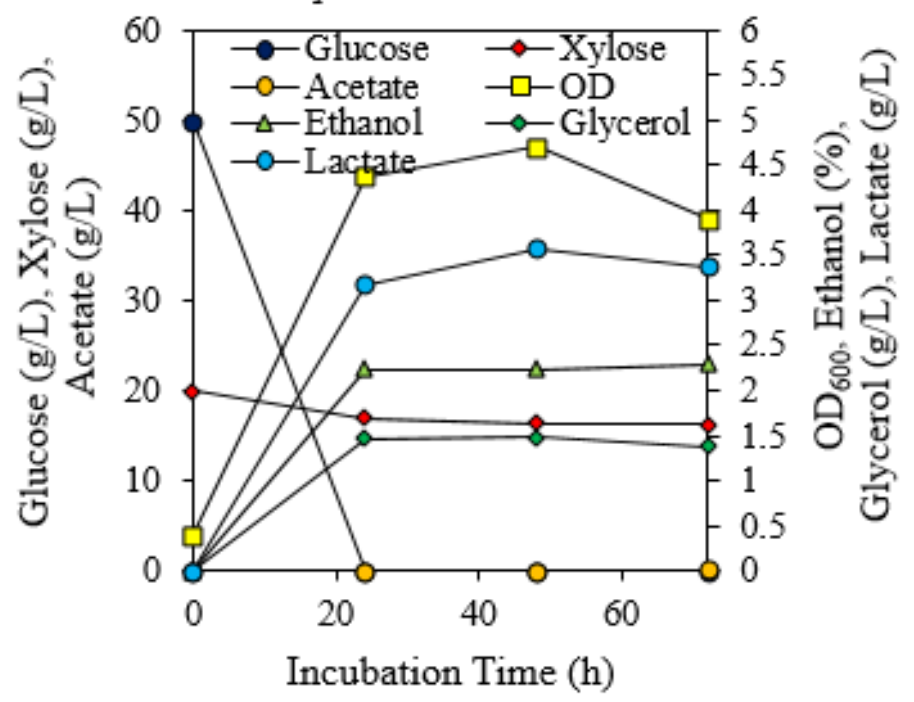

Fcs 4

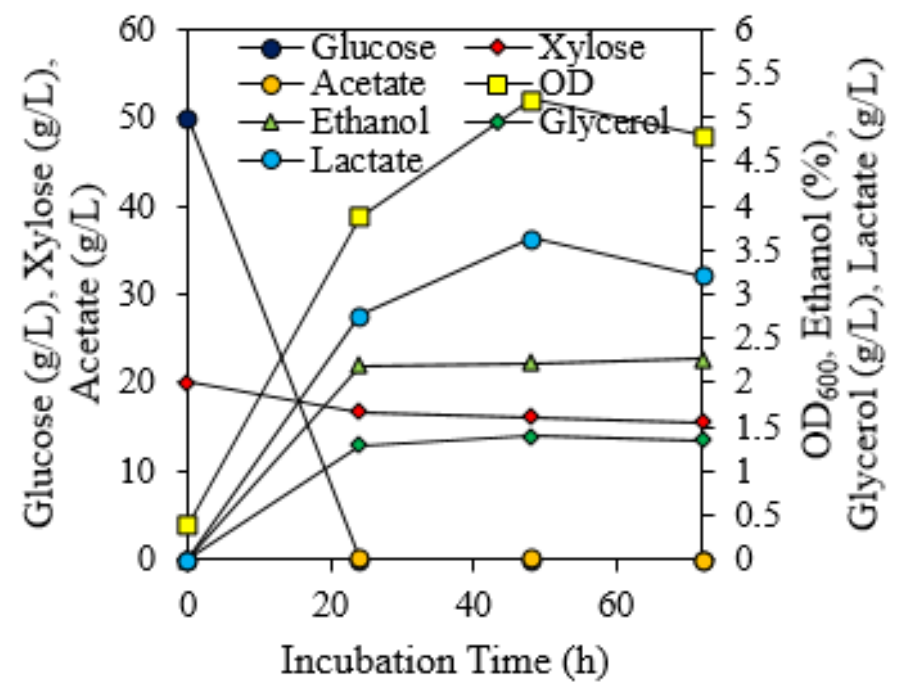

\section{Figure 4}

Performance of parental and mutant yeast bioethanol production on YPXG (20-50 g/L xylose-glucose) 
S. cerevisiae DBY1

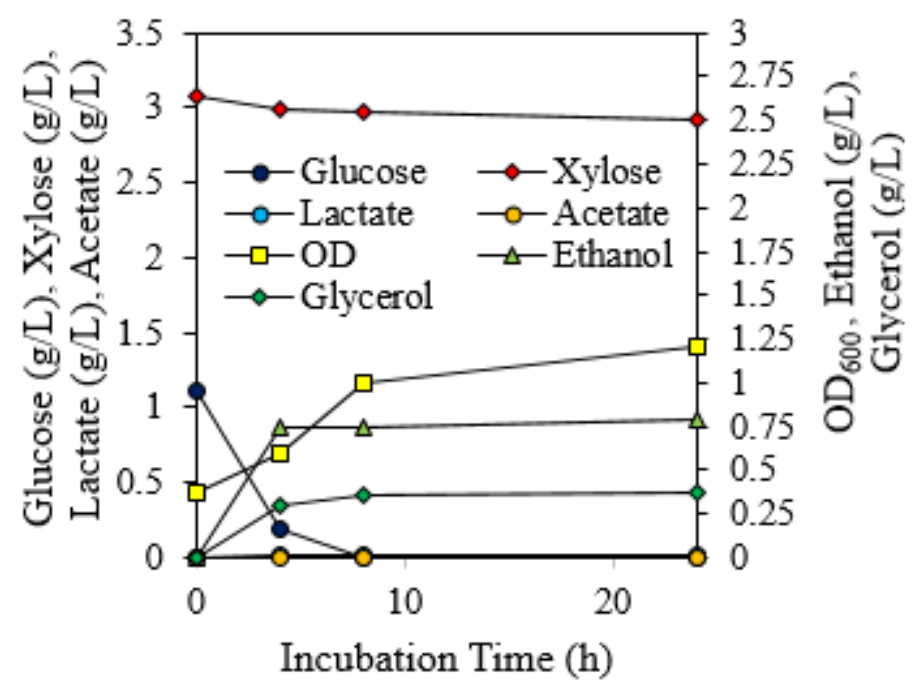

C. tropicalis KBKTI 10.5.1
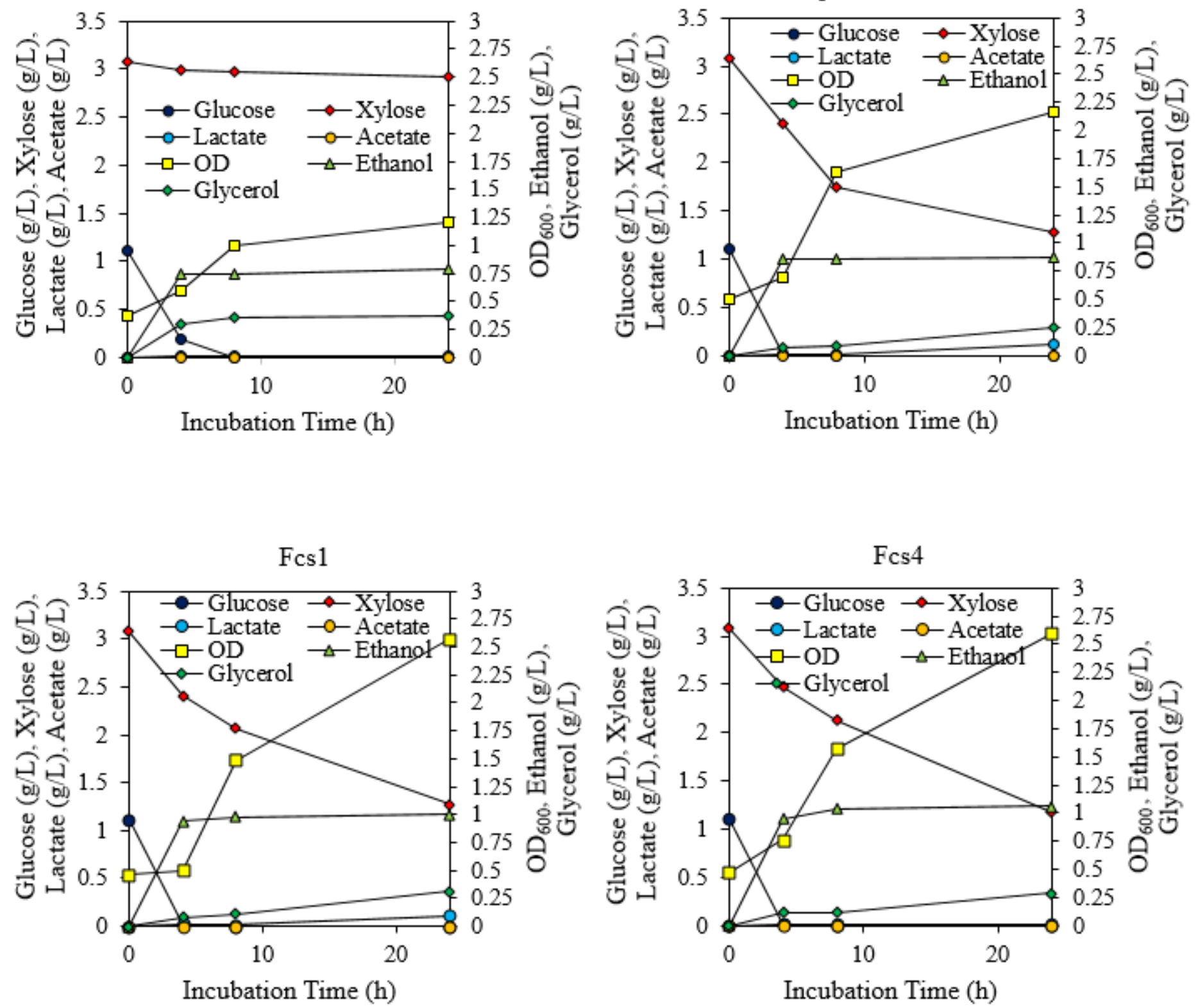

Fcs 4

Fcs1

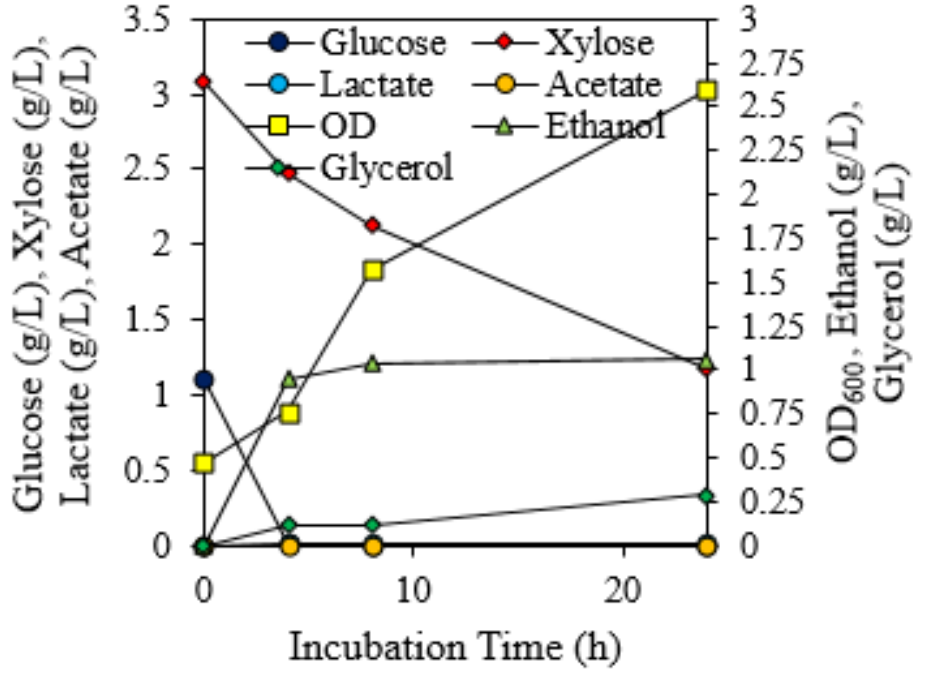

\section{Figure 5}

Performance of parental and mutant yeast bioethanol production on acid hydrolyzate media containing 3.08-1.11 g/L xylose-glucose 
S. cerevisiae DBY1

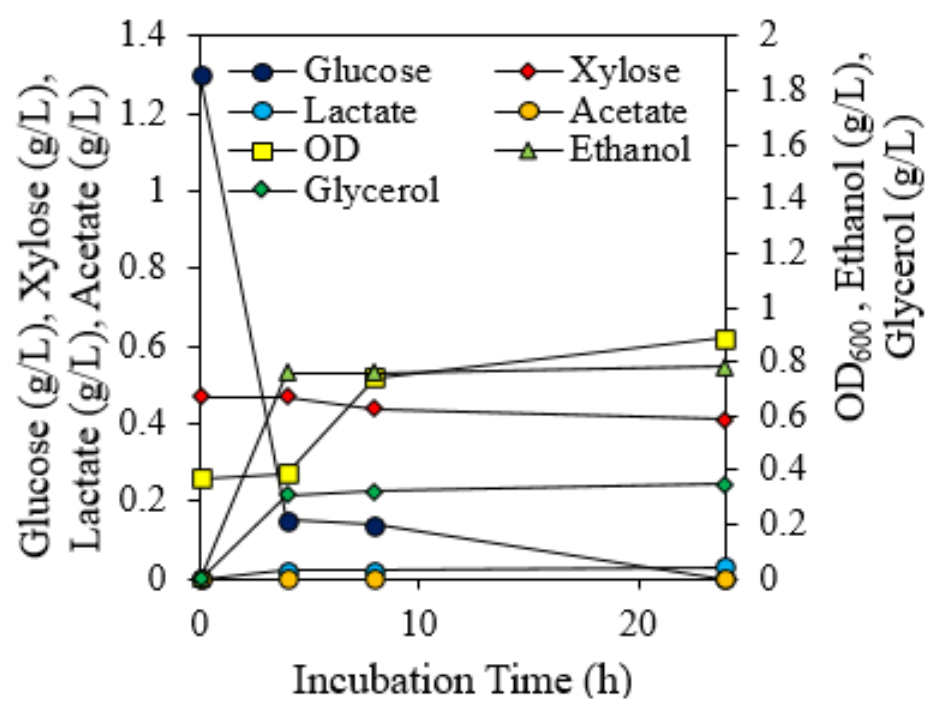

Fcs 1

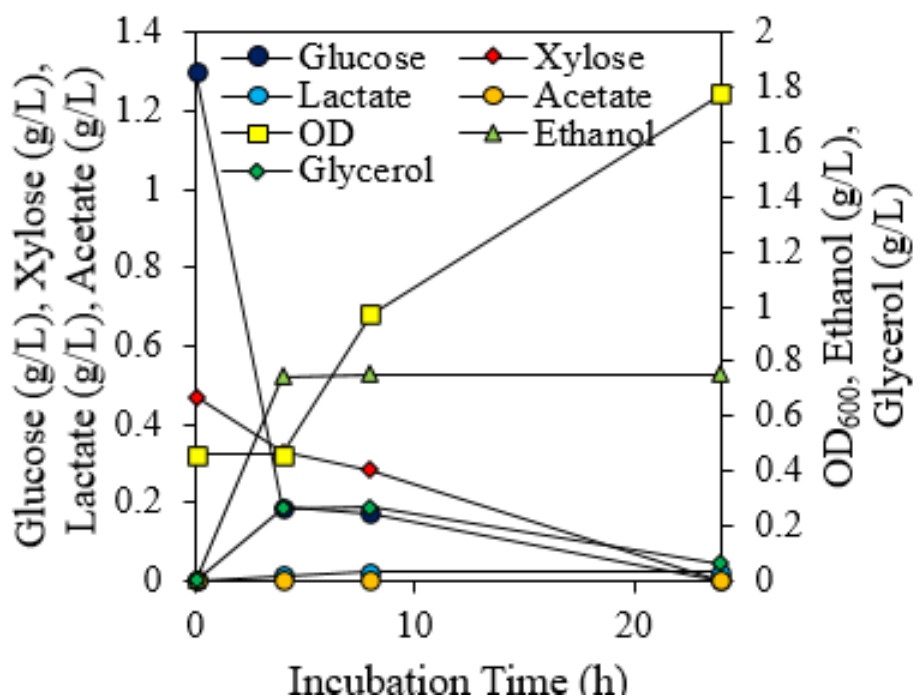

C. tropicalis $\mathrm{KBKTI} 10.5 .1$

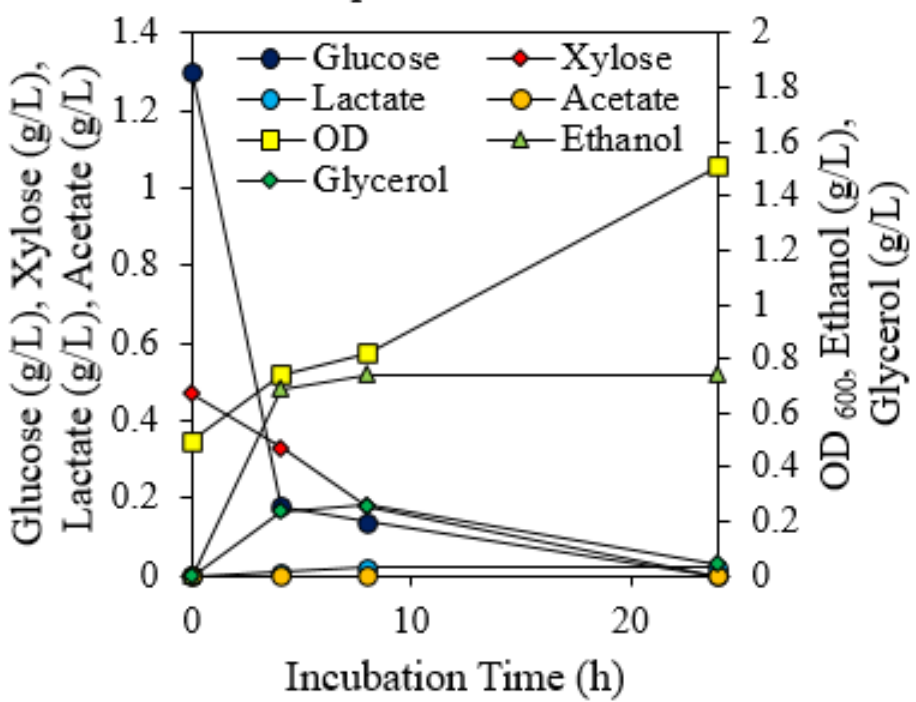

Fcs 4

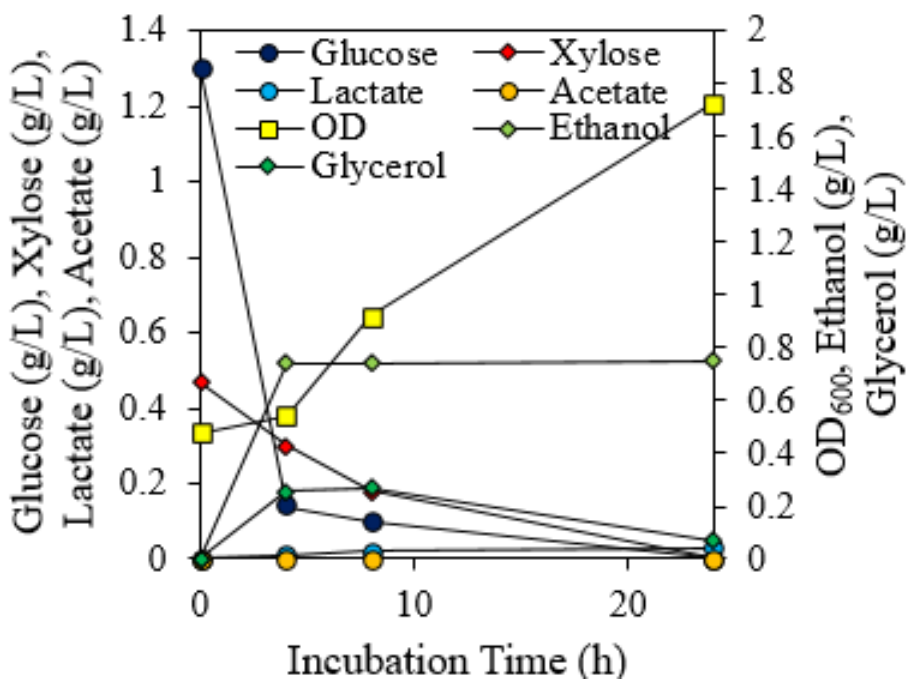

Figure 6

Performance of parental and mutant yeast bioethanol production on base hydrolyzate media containing 0.47-1.30 g/L xylose-glucose

\section{Supplementary Files}

This is a list of supplementary files associated with this preprint. Click to download.

- SupplementaryMaterial.pdf 